\title{
Passiv røyking og risiko for hjerteinfarkt
}

\author{
Erik Dybing ${ }^{1}$ og Tore Sanner ${ }^{2}$ \\ ${ }^{1}$ Avdeling for miljømedisin, Statens institutt for folkehelse, Postboks 4404 Torshov, 0403 Oslo \\ ${ }^{2}$ Avdeling for miljø- og yrkesbetinget kreft, Institutt for kreftforskning, Det Norske Radiumhospital, 0310 Oslo
}

Korrespondanse sendes Erik Dybing

\begin{abstract}
SAMMENDRAG
Tobakksrøyk består av en kompleks blanding av et stort antall kjemiske forbindelser, vesentlig dannet ved ufullstendig forbrenning av tobakk. Begrepet passiv røyking brukes når en person puster i luft som er forurenset med tobakksrøyk. Ved passiv røyking vil en person kunne få i seg like mye av enkelte stoffer i tobakksrøyken som om vedkommende selv hadde røykt opptil flere sigaretter. I artikkelen er det foretatt en gjennomgang av publiserte undersøkelser i forbindelse med hjertesykdommer og passiv røyking. Passiv røyking reduserer blodets transport av oksygen til myokard, samt hjertemuskulaturens evne til å bruke oksygenet i dannelsen av adenosintrifosfat (ATP). Passiv røyking øker blodplatenes aktivitet. I dyreforsøk er det funnet at tobakksrøyk fremskynder aterosklerotiske skader, samt forsterker vevskaden ved reperfusjon. Ikke-røykere som daglig er utsatt for passiv røyking over lengre tid, har en økt risiko både for dødelig og ikke-dødelig hjertesykdom. Det er anslått at det her i landet årlig dør mellom 300 og 500 (henholdsvis lavt og høyt estimat) ikke-røykere som følge av hjertesykdom forårsaket av passiv røyking.
\end{abstract}

Dybing E, Sanner T. Passive smoking and risk of heart disease. Nor J Epidemiol 1995; 5 (2): 135-140.

\section{ENGLISH SUMMARY}

Environmental tobacco smoke (ETS) is a complex mixture of a large number of chemical substances primarily generated by the incomplete combustion of tobacco. The term passive smoking is used when a person breathes in air contaminated with ETS. Passive smoking reduces the blood's ability to deliver oxygen to the myocardium, and reduces the ability of the heart muscle to use oxygen in the formation of adenosine triphosphate. Passive smoking activates blood platelets. Animal experiments have shown that ETS accelerates the development of atherosclerosis. Nonsmokers exposed to ETS daily for long periods have an increased risk for fatal and nonfatal heart disease. It is estimated that annually 300-500 (low and high estimate, respectively) nonsmokers in Norway die due to heart disease caused by passive smoking.

\section{EKSPONERING VED PASSIV RØYKING}

Tobakksrøyk består av en kompleks blanding av et stort antall kjemiske forbindelser, vesentlig dannet ved ufullstendig forbrenning av tobakk. I tillegg kommer stoffer som fordamper ved oppvarming av tobakk (f.eks. nikotin). Den røyken som dannes og pustes inn når røykeren tar et drag av sigaretten, betegnes hovedstrømsrøyken. Den røyken som går ut $\mathrm{i}$ rommet mellom dragene, kalles sidestrømsrøyken. Sidestrømsrøyken inneholder de samme kjemiske stoffer som hovedstrømsrøyken, men det relative mengdeforholdet er forskjellig. For mange av de mest helseskadelige stoffene er det en relativt større mengde i sidestrømsrøyken. For en ikke-filter sigarett er f.eks. forholdet mellom mengdene i sidestrømsrøyken og hovedstrømsrøyken for nikotin 2,6-3,3, for benzen 5-10 og for nitrosodimetylamin 20-100 (1). Ved røyking av filtersigaretter reduseres innholdet av enkelte stoffer i røyken som røykeren puster inn, mens mengden av helseskadelige stoffer i sidestrømsrøyken ikke blir påvirket. Her i landet røyker omtrent halvparten av røykerne håndrullede sigaretter. Disse gir røykerne omtrent dobbelt så mye nikotin og tjære pr. sigarett som fabrikkfremstilte sigaretter. Det er imidlertid grunn til å anta at mengden av helseskadelige stoffer i den røyken som går ut i rommet, er tilnærmet den samme som ved røyking av fabrikkfremstilte sigaretter.

Passiv røyking er et begrep som brukes om å puste i luft som er forurenset med tobakksrøyk. Ved passiv røyking er man hovedsakelig utsatt for sidestrømsrøyk, men i tillegg vil en passiv røyker få i seg noe av det røykeren puster ut og gasser som har diffundert gjennom sigarettpapiret. Ved angivelse av konsentrasjonen 
av tobakksrøyk i omgivelsene brukes ofte nikotin og/eller karbonmonoksid (CO) som en indikator. Tabell 1 viser noen målinger av karbonmonoksid og nikotin (2). Målinger av kotinin som er en metabolitt av nikotin som kan påvises i serum, urin eller spytt, brukes ofte for å angi opptaket av nikotin. En ikkerøyker som er utsatt for passiv røyking i hjemmet eller på arbeidsplassen har vanligvis en kotininkonsentrasjon $\mathrm{i}$ urinen som tilsvarer $0,1-1 \%$ av det man i gjennomsnitt finner hos røykere. Beregninger av Repace og Lowry (3) viser at en amerikansk ikke-røyker som er utsatt for passiv røyking har en kotininkonsentrasjon i urinen som tilsvarer $0,5 \%$ av det man finner hos røykere og at de mest eksponerte passive røykere får en konsentrasjon i urinen som svarer til 5\% av det en gjennomsnittsrøyker har. Regner vi at gjennomsnittsamerikaneren røyker 20 sigaretter om dagen, vil man ved passiv røyking få i seg en menge nikotin som svarer til å røyke 1/10 til 1 sigarett om dagen. På den annen side vil man ved passiv røyking som følge av at ulike kjemiske stoffer fordeler seg ulikt i hovedstrømsrøyken og sidestrømsrøyken, få i seg en mengde av f.eks. det kreftfremkallende stoffet nitrosodimetylamin som tilsvarer røyking av 1 til 10 sigaretter om dagen. Av enkelte stoffer $i$ tobakksrøyken vil man således ved passiv røyking kunne få i seg like meget som om man selv hadde røykt opptil flere sigaretter.

Tabell 1. Eksponering for karbonmonoksid og nikotin i tobakksrøyk ved passiv røyking. Tallene i parentes angir variasjonen $\mathrm{i}$ målingene. Tallene er basert på data i referanse 2 .

\begin{tabular}{lcc}
\hline Lokalisasjon & Karbonmonoksid $\left(\mathrm{mg} / \mathrm{m}^{3}\right)$ & Nikotin $\left(\mu \mathrm{g} / \mathrm{m}^{3}\right)$ \\
\hline Boliger & - & $4,3(1,6-21)$ \\
Kontorer & $3,4(1,1-3,8)$ & $4,1(0,8-22,1)$ \\
Restauranter & $5,8(0,6-11,3)$ & $6,5(3,4-34)$ \\
Barer & $13,3(3,5-19,5)$ & $19,7(7,4-65,5)$ \\
\hline
\end{tabular}

Basert på våre kunnskaper om aktiv røyking og de mengder med helseskadelige stoffer som man blir utsatt for ved passiv røyking, er det ikke uventet at luft forurenset med tobakksrøyk kan gi alvorlige helseskader. Det er vanlig å skille mellom virkninger av passiv røyking som kan opptre ved kortvarig påvirkning og virkning som først finnes etter påvirkning $i$ flere år. Vi har nylig skrevet en oversiktsartikkel om helseskader ved passiv røyking (4) og vil i denne artikkelen bare omtale effekter av passiv røyking på hjerte- og karsystemet og på utvikling av hjerteinfarkt.

\section{EFFEKTMEKANISMER}

Det er velkjent at tobakksrøykens karbonmonoksid (CO) binder seg til hemoglobin og fortrenger oksygen slik at transport av oksygen til myokard blir redusert.
Videre er det vist at passiv røyking hemmer aktiviteten til enzymet cytokrom oksidase i mitokondriene i hjertemuskulaturen slik at det dannes mindre energirikt adenosintrifosfat (ATP) (5). Passiv røyking øker mengden av laktat i blodet, noe som tyder på at hjertet arbeider mer anaerobt enn vanlig (6).

En annen viktig effekt av tobakksrøyk er økt blodplateaktivering, noe som øker sannsynligheten for trombedannelse. Denne effekten skyldes antagelig hemming av enzymet plateaktiverende faktor acetylhydrolase (7). Blodplatene til aktiv-røykere er vanligvis maksimalt aktivert, derfor vil ikke tilleggseksponering for passiv røyk gi noen ytterligere aktivering. Ikke-røykere som utsettes for passiv røyk kan derimot være meget følsomme med hensyn til plateaktivering (8).

Ved lengre tids påvirkning med tobakksrøyk kommer det til skade av endotel, dette kan føre til plateaggregering ved at platene reagerer med subendotelialt bindevev. Slik kan man starte en prosess som leder frem til dannelse av aterosklerotiske plaques. Eksponering for passiv røyk fører til økt forekomst av endotelcellerester uten cellekjerner som tegn på celleskade (9).

Eksponering for passiv røyk er videre vist å føre til lavere plasmanivåer av high density lipoproteiner (HDL) hos ungdom til foreldre som røyker, en slik endring innebærer økt risiko for utvikling av arteriosklerose (10).

Allerede for over tyve år siden fremsatte Benditt og Benditt (11) en hypotese om at proliferasjonen av glatte muskelceller i en aterosklerotisk lesjon skyldes klonal vekst tilsvarende en godartet svulst. Aterosklerotiske plaques kunne således dannes ut fra en somatisk mutasjon som ga den muterte muskelcellen en proliferativ fordel sammenlignet med øvrige celler. Ved hjelp av glukose 6-fosfat dehydrogenase isozymanalyser er det senere fremkommet holdepunkter for at en vesentlig del av humane plaques har monoklonalt utgangspunkt (12). Det er imidlertid fortsatt diskusjon om årsakene til slike mutagene hendelser, idet de kan tenkes å være spontane, eller endogent eller eksogent utløste.

I dyremodeller er det vist at tjærestoffer (PAH) som 7,12-dimetylbenzo(a,h)antracen og benzo(a)pyren, kan forsterke utviklingen av aterosklerose (13). Slike stoffer binder seg selektivt til low density (LDL) og high density lipoproteiner (HDL), slik at endotelceller kan få økt eksponering for dem. Ekstrakter av tobakksrøyk fra omgivelsene, som bl.a. inneholder $\mathrm{PAH}$, gir også økt dannelse av aterosklerotiske plaques $i$ en kaninmodell (14) og i hanekyllinger (15). Denne effekten er direkte og skyldes ikke økt forekomst av sirkulerende katekolaminer.

Selv om mutasjonsteorien ved dannelse av aterosklerotiske plaques er attraktiv, så er det forholdsvis få direkte holdepunkter som underbygger den. Det kan imidlertid tenkes at både endogene og eksogene fak- 
torer spiller inn, og at både initierende (mutasjonsutløsende) og promoverende (fremvekst av initierte celler) er av betydning. Det at forholdsvis kortvarig eksponering for tobakksrøyk i omgivelsene forsterker utvikling av plaques kan tyde på at promosjonsvirkning er viktig (15). I tillegg til direkte gentoksiske forbindelser i tobakksrøyken som PAH og nitrosaminer, er det tenkelig at mutasjoner kan utløses indirekte gjennom dannelse av frie radikaler. Det er kjent at passiv røyking forsterker effekten av iskemi grunnet økt radikaldannelse ved reperfusjonsskade (16). Aktive røykere kan være mindre følsomme enn passive røykere overfor friradikal skade, da de aktive røykerne har forhøyde nivåer av anti-oksidasjonsenzymer i lungene som virker delvis beskyttende (17).

\section{EPIDEMIOLOGISKE UNDERSØKELSER}

Siden den første artikkelen som viste sammenheng mellom passiv røyking og hjerteinfarkt ble publisert i 1985 (18) har det nå kommet omkring 15 artikler (8). Disse studiene har blitt gjennomgått av Wells (19) og Glanz og Parmley (8). Totalt omfatter undersøkelsene 2233 kvinner og 898 menn som har utviklet dødelig eller ikke dødelig hjertesykdom. I figur 1 og 2 er resultatene av de epidemiologiske undersøkelsene oppsummert. Resultatene for effekter er angitt separat for kvinner og menn. Det samlede risikoestimatet er basert på hele materialet.

Syv undersøkelser er publisert når det gjelder dødelig iskemisk hjertesykdom blant ikke-røykende kvinner som er gift med menn som røyker (18,20-25) og fem undersøkelser er publisert om ikke-røykende menn gift med kvinner som røyker $(20,22-24,26)$. Av de 12 studiene viste 11 en økt risiko for ikke-røykere gift med røykere for å dø av iskemisk hjertesykdom etter justering for andre risikofaktorer. I åtte av undersøkelsene ble det funnet at risikoen for hjertedød økte med antall sigaretter som ektefellen røykte. I tillegg til dette kommer to undersøkelser som bare er publisert som abstrakt og som begge viste økt risiko $(32,33)$. Ved å benytte samme fremgangsmåte som US Environmental Protection Agency anvendte ved beregning av risikoen for lungekreft har Wells (19) på basis av alle undersøkelsene beregnet den relative risikoen for å dø av iskemisk hjertesykdom blant ikke-røykere som bor sammen med en røyker til 1,2 (95\% konfidensintervall 1,1-1,4). Dersom Wells bare tok hensyn til de 5 undersøkelsene som hadde den beste kontrollen på samvirkende faktorer økte den beregnede relative risikoen for å dø av hjertesykdom blant ikke-røykere som bor sammen med en røyker til 1,7 (95\% konfidensintervall 1,3-2,3) (19).

I tillegg til undersøkelsene hvor død var endepunktet, var det 11 undersøkelser som hadde en ikkedødelig hjerteepisode som endepunkt (fig. 2). Endepunktet omfattet hjerteinfarkt, angina, og maligne elektrokardiografiske forandringer. $\mathrm{Ni}$ av de 11 under- søkelsene viste økt risiko for disse lidelsene ved å bo sammen med en røyker. Wells (19) beregnet den relative risikoen for ikke-dødelig hjerteepisode blant ikkerøykere som bodde sammen med en røyker til 1,3 (95\% konfidensintervall 1,1-1,6). I tre av undersøkelsene ble det funnet en klar dose-respons sammenheng.

Det faktum at de epidemiologiske undersøkelsene, utført i flere forskjellige land og justert for en rekke andre risikofaktorer for hjertesykdom viser såpass like resultater sammen med de eksperimentelle undersøkelsene omtalt ovenfor, styrker konklusjonen om at passiv røyking øker risikoen både for dødelig og ikkedødelig hjertesykdom. Spørsmålet reiser seg imidlertid om en økning av sykdomsrisiko på $20-30 \%$ kan være rimelig ut fra eksponeringsnivå og våre kunnskaper om effektene av røyking på risikoen for å utvikle hjertesykdom.

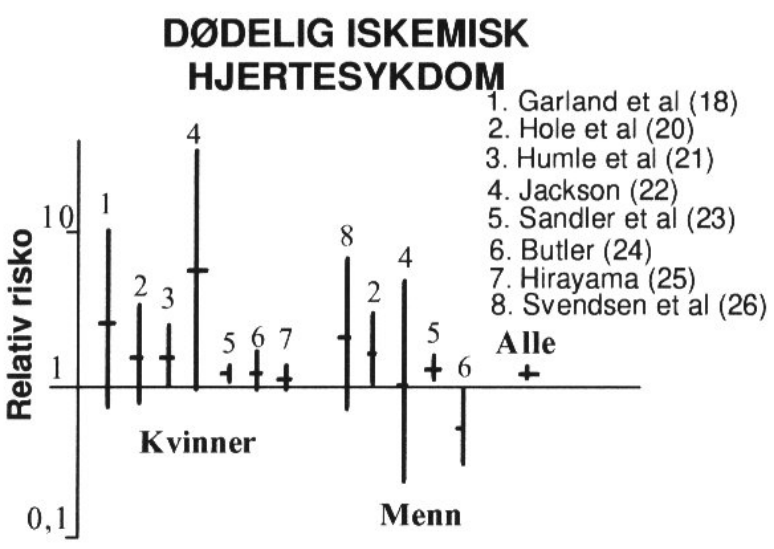

Figur 1. Effekt av passiv røyking på risikoen for dødelig iskemisk hjertesykdom fra publiserte epidemiologiske undersøkelser. "Alle" representerer et samlet risikoestimat beregnet av Wells (19). De vertikale streker angir $95 \%$ konfidensintervall.

IKKE - DØDELIG ISKEMISK HJERTESYKDOM 1 . Hee et al (27) 2. Hee et al (28) 3. Hole et al (20) 4. Dobson et al (29) 5. Jackson (22) 6. Lee (30)

7. Svendsen et al (26)

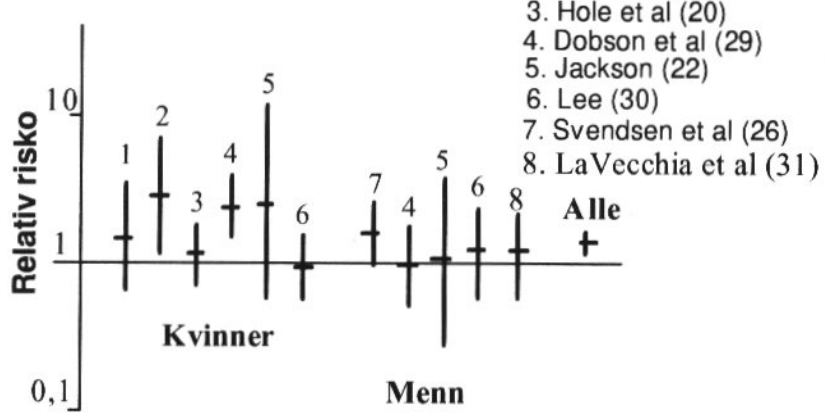

Figur 2. Effekt av passiv røyking på risikoen for ikkedødelig iskemisk hjertesykdom fra publiserte epidemiologiske undersøkelser. "Alle" representerer et samlet risikoestimat beregnet av Wells (19). De vertikale streker angir $95 \%$ konfidensintervall. 
Risikoen for å dø av hjertesykdom som følge av aktiv røyking synes å øke raskt ved et lite antall sigaretter for så å vise en noe mindre økning pr. sigarett ved et høyere daglig forbruk. Rosengren et al. (34) har $i$ en svensk undersøkelse beregnet odds ratio for hjertesykdom blant menn som røyker 1-4 sigaretter daglig til 2,8 (95\% konfidensintervall 1,7-4,7). Willett et al. (35) har tilsvarende beregnet en relativ risiko blant kvinner som røyker 1-4 sigaretter daglig til 2,4 (95\% konfidensintervall $1,1-5,0$ ). Regner vi at røykerne i de to undersøkelsene i gjennomsnitt røykte 2,5 sigaretter og at dette gir en relativ risiko på 2,6, så vil vi dersom vi ekstrapolerer lineært ved røyking av 0,25 sigaretter daglig få en teoretisk relativ risiko på 1,16 . I eksponeringsvurderingene nevnt tidligere i artikkelen, ble det påpekt at en amerikaner som utsettes for passiv røyking i gjennomsnitt får i seg en mengde nikotin som svarer til det å røyke 1/10 sigarett og en mengde med nitrosodimetylamin som svarer til å røyke 1 sigarett om dagen. Videre påpeker Glantz og Parmley (8) at flere av de effektene som er knyttet til økt risiko for hjerteinfarkt ved passiv røyking, er kraftigere enn dem man ville forvente fra aktiv røyking. En økt risiko for iskemisk hjertesykdom ved passiv røyking på 1,2 til 1,3 er derfor ikke urimelig.

I USA er det anslått at mellom 30000 og 60000 ikke-røykere årlig dør av iskemisk hjertesykdom som følge av passiv røyking. I tillegg kommer omkring 3000 dødsfall av lungekreft. Passiv røyking blir dermed den tredje viktigste dødsårsak som man kan forebygge. Det er bare aktiv røyking og bruk av alkohol som krever flere liv. De anslåtte tallene for dødelighet av hjertesykdom som følge av passiv røyking representerer forholdene på slutten av 1980-tallet. Wells (19) beregnet at det i 1985 døde 62000 amerikanere av iskemisk hjertesykdom som følge av passiv røyking, men at dette tallet i 1994 var redusert til 47000 som følge av at andelen røykere har gått ned (i USA røyker nå $25 \%$ av befolkningen sammenliknet med $35 \%$ i Norge) og at det har kommet lover og forskrifter som beskytter mot passiv røyking på arbeidsplasser. Amerikanske arbeidsmiljømyndigheter (36) har beregnet at av 1000 arbeidere utsatt for passiv røyking i hele sitt arbeidsaktive liv vil mellom 7 og 16 utvikle hjertesykdom som følge av tobakksrøyk i omgivelsene.

Ved beregning av hvor mange dødsfall man vil kunne forvente i Norge som følge av utvikling av hjertesykdom i forbindelse med passiv røyking, har vi basert oss på risikoestimatet til Wells (19). Han angir en relativ risiko på 1,22 basert på hele sitt materiale. Dette er sannsynligvis et nedre estimat siden den relative risikoen blir 1,79 dersom den beregnes på basis av de undersøkelsene som er best kontrollert for andre faktorer. Det er grunn til å anta at den relative risikoen kan være tilnærmet den samme i Norge som i USA siden både antall dødsfall av hjertesykdom pr. 100000 og eksponeringsnivåene for tobakksrøyk i omgivelsene (37) synes å være tilnærmet de samme i begge landene. I de fleste studier som gjøres på risikofaktorer for hjertesykdom, brukes multiplikative modeller. Siden komponentene man eksponeres for ved passiv røyking er de samme som ved aktiv røyking, er det rimelig å anvende de samme modeller ved beregning av risiko ved passiv røyking som ved aktiv røyking.

Dersom man antar at $15 \%$ av den voksne befolkningen er utsatt for passiv røyking enten på arbeidsplassen eller i hjemmet kan man beregne at omtrent 300 personer årlig dør av hjertesykdom som følge av passiv røyking. Regner man derimot at $25 \%$ er utsatt for passiv røyking blir tallet 500 personer. Siden risikoestimatet som er brukt på den ene siden kan være noe lavt, men at antall eksponerte kanskje er noe høyt, har vi tidligere konkludert med at antall dødsfall av hjertesykdom som skyldes passiv røyking her i landet årlig er mellom 300 og 500 (38).

\section{REFERANSER}

1. U.S. Environmental Protection Agency. Respiratory Health Effects of Passive Smoking: Lung Cancer and Other Disorders. EPA/600/6-90/006F. Washington, D.C., 1992.

2. Siegel M. Involuntary smoking in the restaurant workplace. A review of employee exposure and health effects. JAMA 1993; 270: 490-3.

3. Repace JL, Lowrey AH. An enforceable indoor air quality standard for environmental tobacco smoke in the workplaces. Risk Analysis 1993; 13: 463-75.

4. Sanner T, Dybing E. Helseskader ved passiv røyking. Tidsskr Nor Laegeforen, innsendt for publisering.

5. Gvodsdjak J, Gvozdjakova A, Kucharska J, Bada V. The effect of smoking on myocardial metabolism. Czech Med 1987; 10: 47-53.

6. McMurray RG, Hicks LL, Thompson D. The effects of passive inhalation of cigarette smoke on exercise performance. Eur J Appl Physiol 1985; 54: 196-200.

7. Miyaura S, Eguchi H, Johnson J. Effect of a cigarette smoke extract on the metabolism of the proinflammatory autacoid, platelet-activating factor. Circ Res 1992; 70: 3431-7. 
8. Glantz SA, Parmley WW. Passive smoking and heart disease. Mechanisms and risk. JAMA 1995; 273: 104753.

9. Davis J, Shelton L, Watanabe I, Arnold J. Passive smoking affects endothelium and platelets. Arch Intern Med 1989; 149: 386-9.

10. Feldman J, Shenker IR, Etzel RA, et al. Passive smoking alters lipid profiles in adolescents. Pediatrics 1991; 88: $259-64$.

11. Benditt EP, Benditt JM. Evidence for a monoclonal origin of human atherosclerotic plaques. Proc Natl Acad Sci USA 1973; 70: 1753-6.

12. International Commission for Protection Against Environmental Mutagens and Carcinogens. The possible involvement of somatic mutations in the development of atherosclerotic plaques. Report of ICPEMC Subcommittee 7/1. Conclusions and recommendations. Mutat Res 1990; 239: 143-8.

13. Glantz SA, Parmley WW. Passive smoking and heart disease: epidemiology, physiology, and biochemistry. Circulation 1991; 83: 1-12.

14. Zhu B-Q, Sun Y-P, Sievers R, Isenberg R, Glantz SA, Parmley WW. Passive smoking increases experimental atherosclerosis in cholesterol-fed rabbits. J Am Coll Cardiol 1993; 21: 225-32.

15. Penn A, Snyder CA. Inhalation of sidestream cigarette smoke accelerates development of artiosclerotic plaques. Circulation 1993; 88: 1820-5.

16. Przylenk K. Nicotine exacerbates postischemic contractile dysfunction of 'stunned' myocardium in the canine model: possible role of free radicals. Circulation 1994; 89: 1272-81.

17. McCusker K, Hoidal J. Selective increase of antioxidant enzyme activity in the alveolar macrophages from cigarette smokers and smoke-exposed hamsters. Am Rev Respir Dis 1990; 141: 678-82.

18. Garland C, Barrett-Connor E, Suarez L, Criqui M, Wingard D. Effects of passive smoking on ischemic heart disease mortality of nonsmokers. Am J Epidemiol 1985; 121: 645-50.

19. Wells AJ. Passive smoking as a cause of heart disease. J Am Coll Cardiol 1994; 24: 546-54.

20. Hole DJ, Gillis CR, Chopra C, Hawthorne VM. Passive smoking and cardiorespiratory health in a general population in the west of Scotland. BMJ 1989; 299: 423-7.

21. Humble C, Croft J, Gerber A, Hames C, Tyroler H. Passive smoking and twenty year cardiovascular disease mortality among nonsmoking wives in Evans County, Georgia. Am J Public Health 1990; 80: 599-601.

22. Jackson RT. The Auckland Heart Study. Auckland, New Zealand: University of Auckland, 1989: 157-72.

23. Sandler DP, Comstock GW, Helsing KJ, Shore DL. Deaths from all causes in nonsmokers who lived with smokers. Am J Public Health 1989; 79: 163-7.

24. Butler TL. The relationship of passive smoking to various health outcomes among seventh-day adventists in California. Los Angeles: University of California, 1988.

25. Hirayama T. Passive smoking. N Z Med J 1990; 103; 54.

26. Svendsen KH, Kuller LH, Martin MJ, Ockene JK. Effects of passive smoking in the multiple risk factor intervention trial. Am J Epidemiol 1987; 126: 783-95.

27. He Y, Li L-S, Wan Z-H, Li L-S, Zeng X-L, Gru L-L. Women's passive smoking and coronary heart disease. Chung Hua Yu Fang I Hsueh Tsa Chih 1989; 23: 19-22.

28. He Y, Lam TH, Li TS, et al. Passive smoking at work as a risk factor for coronary heart disease in Chinese women who have never smoked. BMJ 1994; 308: 380-4.

29. Dobson AJ, Alexander HM, Heller RF, Lloyd DM. Passive smoking and the risk of heart attack or coronary death. Med J Aust 1991; 154: 793-7.

30. Lee PN, Chamberlain J, Alderson MR. Relationship of passive smoking to risk of lung cancer and other smoking related disease. Br J Cancer 1986; 54: 97-105.

31. La Vecchia C, D'Avanzo B, Franzosi MG, Tognoni G. Passive smoking and the risk of acute myocardial infarction (letter). Lancet 1993; 341: 505-6.

32. Hunt SC, Martin MJ, Williams RR. Passive smoking by nonsmoking wives is associated with an increased incidence of heart disease. In: Program and abstracts of the annual meeting of the American Public Health Association. Las Vegas, 1986.

33. Palmer J, Rosenberg L, Shapiro S. Passive smoking and myocardial infarction. CVD Epidemiol Newslett 1988; 43: 29.

34. Rosengren A, Wilhelmsen L, Wedel H. Coronary heart disease, cancer and mortality in male middle-aged light smokers. $J$ Int Med 1992; 231: 357-62. 
35. Willett WC, Green A, Stampeer MJ, Speizer FE, Colditz GA, Rosner B, Monson RR, Stason W, Hennekens $\mathrm{CH}$. Relative and absolute excess risks of coronary heart disease among women who smoke cigarettes. $N$ Engl J Med 1987; 317: 1303-9.

36. Department of Labor. Occupational Safety and Health Administration. 29 CFR Parts 1910, 1915, 1926, and 1928 Indoor Air Quality; Proposed Rule. Fed Reg 1994; 59: 15968-6039.

37. Helsedirektoratets utredningsserie 6-90. Retningslinjer for inneluft-kvalitet. Rapport fra arbeidsgruppe oppnevnt av Helsedirektoratet. Oslo, 1990.

38. Sanner T, Dybing E. Helseskader ved passiv røyking. I Helsekonsekvenser ved røyking. Tobakk og kvinner. En rapport fra helseministeren 1994. Redaktør T Sanner. Sosial- og helsedepartementets arbeidsgruppe for røykfritt Norge. Oslo, 1994. 